\title{
Legal Perception of the Community Regarding Productive Zakat and Its Utilization In Makassar
}

\author{
Zainuddin $Z^{1}$, Hasbuddin Khalid ${ }^{2}$ \\ ${ }^{1}$ Faculty of Law, Universitas Muslim Indonesia, Indonesia, Email: \\ zainuddin.zainuddin@umi.ac.id \\ ${ }^{2}$ Faculty of Law, Universitas Muslim Indonesia, Indonesia, Email: \\ hasbuddinkhalid@umy.ac.id
}

\begin{tabular}{|c|c|}
\hline Article Info & Abstract \\
\hline $\begin{array}{l}\text { Keywords: } \\
\text { Legal Perception, } \\
\text { Zakat, Utilization of Zakat } \\
\text { How to cite: } \\
\text { Zainuddin Z, Hasbuddin Khalid, } \\
\text { "Legal Perception of Community } \\
\text { Regarding Productive Zakat and } \\
\text { Its Utilization In Makassar," Fiat } \\
\text { Justisia: Jurnal Ilmu Hukum 14, } \\
\text { No. } 1 \text { (2020): 69-82. } \\
\text { 10.25041/fiatjustisia.v14no1.1796 }\end{array}$ & $\begin{array}{l}\text { Zakat is one of the pillars of Islam that must be } \\
\text { fulfilled by all Muslims. Zakat in its } \\
\text { implementation, must be determined and regulated } \\
\text { by religion and the state. This study aims (1) To } \\
\text { find out and analyze the legal perceptions of } \\
\text { mustahiq (zakat receiver) regarding productive } \\
\text { zakat in Makassar; and (2) to find out and analyze } \\
\text { the legal perception of mustahiq regarding the } \\
\text { productive utilization zakat in Makassar. This } \\
\text { research is based on legal research conducted with } \\
\text { an empirical juridical approach, which sees the law } \\
\text { not only as a set of normative norms or what } \\
\text { becomes the text of the law but also looks at how } \\
\text { the law interacts with the community (law in } \\
\text { action). This research will be conducted in } \\
\text { Makassar. In this study, the analysis used } \\
\text { qualitative analysis and quantitative analysis was } \\
\text { carried out based on primary data regarding the } \\
\text { opinions of informants in the frequency } \\
\text { distribution. The results achieved in this study are } \\
\text { Makassar community perceives that productive } \\
\text { zakat is the same position as consumptive zakat } \\
\text { which is spent on household needs. Mustahiq } \\
\text { provided revolving funds through qardhul hasan } \\
\text { loans more to spend for household needs or } \\
\text { consumer goods so that it does not provide benefits } \\
\text { as a productive business. Zakat funds in the form of } \\
\text { qardhul hasan loans provided by the Baznas } \\
\text { Makassar should be used for productive ventures. } \\
\text { Besides, the people of Makassar community still } \\
\text { perceive that the funds lent from the Baznas } \\
\text { Makassar do not need to be returned because they } \\
\text { consider that the funds are their rights as poor } \\
\text { people and their use is for consumptive purposes } \\
\text { and there is no obligation to return the zakat funds. } \\
\text { Funding loans under the qardhul hasan scheme }\end{array}$ \\
\hline
\end{tabular}




\section{A. Introduction}

Zakat is one of the pillars of Islam that must be fulfilled by all Muslims. Zakat in its implementation, must be determined and regulated by religion and the state. The principle of zakat covers the very broad bases namely zakat is an obligation to carry out economic duties (avoiding the accumulation of wealth in a small group of wealthy people), social (zakat enables the implementation of the responsibilities of rich people to help the mustahiq meet their needs) and responsibility moral (zakat purifies the property owned so that his property is rewarded by Allah almighty).

Islamic instruments relating to improving the quality of humanity through the distribution of assets are zakat. Zakat is a religious institution that functions to realise social justice for all humankind by paying attention and increasing concern for the poor. Zakat is an economic instrument that is intended as a reduction of economic inequality that occurs in society. ${ }^{1}$

The existence of property zakat, and profession zakat are expected to reduce the level of inequality in Indonesia, besides that zakat can also be relied upon as one mechanism in overcoming the problem of poverty that occurs in Indonesia, through the productive zakat program. According to Muhammad Ridwan, as quoted by Mila Sartika, ${ }^{2}$ that zakat has a very strategic role in efforts to reduce poverty or economic development. In contrast to other sources of finance for development, zakat does not have any backlash except for the approval and expect merit from Allah alone. However, it does not mean the mechanism of zakat does not have a control system. The strategic value of zakat can be seen through: First, zakat is a religious calling. It is a reflection of one's faith. Secondly, the financial resources of the zakat will never stop. This means that people who pay zakat will never run out and who have paid every year or another period will continue to pay. Third, zakat can empirically eliminate social inequalities and vice versa can create asset redistribution and equitable development.

The regulation of zakat in law is one of the economic policies of the Indonesian government whose source is from Islamic teachings which is a potential source of funds for efforts to create public welfare based on social justice. To make zakat a source of funds that can be utilized for the welfare of society, especially in terms of overcoming the problem of poverty, it is

\footnotetext{
${ }^{1}$ Zainuddin Z, "Pemaknaan Ulang Ar- Riqab dalam Upaya Optimalisasi Fungsi Zakat Bagi Kesejahteraan Umat," Jurnal Hukum Ius Quia Iustum 25, No. 3 (2018): 601-622. https://doi.org/10.20885/iustum.vol25.iss3.art9.

2 M. Sartika, "Pengaruh Pendayagunaan Zakat Produktif terhadap Pemberdayaan Mustahiq pada LAZ Yayasan Solo Peduli Surakarta," La_Riba 2, No. 1 (2008): 75-89. https://doi.org/10.20885/lariba.vol2.iss1.art6.
} 
necessary to arrange zakat implementation, both in its sources, ways of collecting it and in its management and distribution. ${ }^{3}$

The government's attention to the Zakat Management Organization is also quite large. After issuing Law No. 38 of 1999 concerning Management of Zakat, in 2011, the government issued Law No. 23 of 2011 as a revision of Law No. 38 of 1999 The formation of this Act is expected to be able to improve the zakat management system in Indonesia so that the optimisation of zakat can be achieved.

Productive Zakat is a form of distribution of zakat funds that are currently being developed. According to Abdurrahman Qadir, ${ }^{4}$ productive zakat is zakat given to mustahiq as capital to carry out an economic activity that is to grow the economic level and potential of mustahiq productivity. The Baznas Makassar and Amil Zakat Board (LAZ) in Makassar role in distributing zakat to mustahiq that are productive in the form of venture capital so that the charity can scroll and rotation.

Based on the description above, it is necessary to study in the form of research on the legal perception of the community regarding zakat productive and its utilization in Makassar by raising the issue: What is the legal perception of the community regarding productive zakat in Makassar? What is the legal perception of the community regarding the management of productive zakat conducted by the National Zakat Board (Baznas) of Makassar and Amil Zakat Board (LAZ) in Makassar?

\section{B. Discussion}

\section{Mustahiq's Legal Perception Regarding Productive Zakat in Makassar}

Zakat is one of the pillars of Islam is a State fiscal instrument that functions not only to distribute the welfare of the people more equitably and evenly but also an integral part of human accountability to Allah SWT and the sustenance $\mathrm{He}$ has provided. Therefore the role of government in managing zakat cannot be neglected so that the purpose of zakat can be achieved which serves the welfare of the community. ${ }^{5}$ Zakat is an important aspect of Islamic teachings. Because zakat is a religious obligation and a treasure at the same time. Zakat is mentioned in the Qur'an as many as 30 times and as many as 27 times the zakat mentioned along with the practice

\footnotetext{
${ }^{3}$ Zainuddin Z, "Hakikat Pengelolaan Zakat dalam Mewujudkan Jaminan Keadilan Sosial di Indonesia", Jurnal Penelitian Hukum Universitas Hasanuddin 1, No. 1 (2011): 110-129.

${ }^{4}$ A. Qadir, Zakat dalam Dimensi Mahdhah dan Sosial (Jakarta: Raja Grafindo Persada, 2001), 83.

${ }^{5}$ Zainuddin Z,“Optimalisasi Peran Pemerintah Dalam Pengelolaan Zakat,” Jurnal Ishlah 14 No. 1 (2012): 19-34.
} 
of prayer and once mentioned in the same context as prayer but not in one verse. ${ }^{6}$

Zakah from the etymology of the word comes from the Arabic language. The word zakah known as a root word (masdar) from the word 'zakka' which means blessing, grow, clean and good. ${ }^{7}$ Zakat cannot be seen as a good service for the rich to the poor or needy, or it is seen as a gift only, because zakat in Islam is a social obligation, as a legal right for mustahiq which in its implementation requires government authority to participate in managing it. ${ }^{8}$ According to Muhammad, ${ }^{9}$ zakat is assets taken from the trust that is managed by rich people, which are transferred to the needy and poor groups as well as other groups that have been determined in the Qur'an, which are commonly called mustahiq groups. In economic terms, a zakat is an act of transfer of wealth from the rich group (agniya/the have) to the group that does not have (they have not).

In general, productive zakat is the utilization of zakat productively whose understanding is more on how or how to deliver zakat funds to the target in a broader sense, following the spirit and purpose of sharia'. How to give effective, effective benefits with a versatile and productive system, following the message of the Shari'a and the role and socio-economic function of zakat. ${ }^{10}$ Management of zakat by zakat management institutions, especially those that have the formal legal power, have several advantages, including first, to guarantee the certainty and discipline of zakat payment. Second, to maintain the feeling of inferiority of the mustahiq of zakat when dealing directly to receive alms from the muzakki. Third, for efficiency and effectiveness, and the right target in the use of zakat assets based on the scale of priorities that exist in a place. Fourth, to show the symbolism of Islam in the spirit of organizing an Islamic government. Conversely, if the implementation of zakat is given directly by muzakki (zakat giver) to mustahiq, then the fate and rights of the poor do not get definite guarantees. ${ }^{11}$

There are eight categories of deserving persons mentioned in this verse. Among the eight categories are those who are in long-term poverty - the poor, the needy and the slaves. There are also those who are temporarily

${ }^{6}$ Zainuddin Z, "Hakikat Pengelolaan Zakat dalam Mewujudkan Jaminan Keadilan Sosial di Indonesia," Jurnal Penelitian Hukum Universitas Hasanuddin 1, No. 1 (2011): 110-129.

7 W. Khairuldin, W. M. K. Firdaus, \& Mohammad M, "The Philosophy and Elasticity of Zakah Distribution in Islam," International Journal of Education and Research 1, No. 8 (2013): 179-190.

${ }^{8}$ M. T. Hasan, Islam dalam Perspektif Sosio Kultural (Jakarta: Lantabora Press, 2005), 255.

9 Muhammad, Lembaga Ekonomi Mikro Syari'ah: Pergulatan Melawan Kemiskinan dan Penetrasi Ekonomi Global (Yogyakarta: Graha Ilmu, 2009), 55.

${ }^{10}$ Asnaini, Zakat Produktif Dalam Perspektif Hukum Islam (Yogyakarta: Pustaka Pelajar, 2008), 64.

11 A. Qadir, Zakat dalam Dimensi Mahdhah dan Sosial (Jakarta: Raja Grafindo Persada, 2001), 87. 
poor such as those in debt and wayfarers who need help. The other two categories (fi sabilillah and muallaf) are for protection and propagation of Islam (jihad and da'wah/preaching) and one category is for financing the zakahinstitution's administrative costs (amil). ${ }^{12}$ Among the mustahiq of zakat who are entitled to receive productive zakat are the poor and needy, amil (those in charge of administering zakat), muallaf (muslim converts). But what is more preferred among this mustahiq is poor and needy. Besides they only get consumptive zakat or certain needs such as Ibn Sabil, Fi Sabilillah, Gharimin, and slaves.

Tabel below shows clearly on the distribution of zakat mustahiq to obtain productive as follows:

Table 1. Distribution of Mustahiq that Receives Earning Zakat

\begin{tabular}{|c|l|c|c|}
\hline No. & Mustahiq & Productive & Non-productive \\
\hline 1. & Faqir & $\checkmark$ & $\checkmark$ \\
2. & Poor & $\checkmark$ & $\checkmark$ \\
3. & Amil & $\checkmark$ & $\checkmark$ \\
4. & Convert & $\checkmark$ & $\checkmark$ \\
5. & Riqab & - & $\checkmark$ \\
6. & Gharimin & - & $\checkmark$ \\
7. & Ibn Sabil & - & $\checkmark$ \\
8. & Fi Sabilillah & - & $\checkmark$ \\
\hline
\end{tabular}

Source: Processed from Secondary Data, 2018

Based on the table above, four groups receive productive charity, namely: the needy, poor, amil, and converts. The indigent and disadvantaged groups are the priority in receiving productive zakat so that they are empowered with this type of zakat. As for amilin and muallaf in their origin, they can also be given zakat in this form, but this will be adjusted to the conditions of the times whether it is needed or not.

Innovation forms of zakat distribution are categorized in four forms: First, the distribution of traditional consumptive nature, namely zakat distributed to mustahiq to be used directly, such as zakat fitrah, or zakat mal which is distributed to victims of natural disasters. Second, distribution is creative consumptive. i.e. zakat which is manifested in other forms of the original goods, as given in the form of school equipment or scholarships. Third, the distribution of traditional productive nature, namely zakat is given in the form of productive goods such as goats, cows, and so forth. Giving in

${ }^{12}$ R. Abdullah, A. R. A. Haqqi, "Zakah for Asnaf Al-Gharimun in Brunei Darussalam: Concepts and Practices," Al-Iqtishad: Jurnal Ilmu Ekonomi Syariah 9, No. 2 (2017): 243258. https://doi.org/10.15408/aiq.v9i2.5092. 
this form can create businesses that open jobs for the poor. Fourth, distribution in the form of creative productive, namely zakat is realized in the form of capital either to increase the capital of small business traders or build social projects and economic projects. ${ }^{13}$

The National Amil Zakat Agency of Makassar (Baznas Makassar) has distributed funds to Mustahiq in the Makassar City Region. Baznas Makassar is a non-structural institution that is independent and has the authority to carry out the task of managing zakat nationally. Based on Makassar Regulation Number 5 of 2006 concerning zakat management, the name was changed to the Makassar Amil Zakat Board (BAZDA). Because of the development of zakat management and reshuffle conducted by the government with the issuance of Law No. 23 of 2011 concerning Management of Zakat, the Bazda Makassar was changed to the Baznas Makassar which is currently chaired by $\mathbf{M}$ Anis Zakaria Kama and Baznas Makassar having their address at Jalan Teduh Bersinar No. 5 Makassar.

The Baznas Makassar organizes an empowerment program. This poor community empowerment program is explicitly handled by the distribution and utilization of zakat, which is headed by Abd. Aziz Bennu by providing economic assistance in the form of venture capital. Productive zakat/business capital mustahiq sourced from loan capital assistance provided by the Baznas Makassar. According to Patmawati Ibrahim \& Ruziah Ghazali, there are two categories of Zakah Micro Finance (ZMF) recipients in this zakah distribution system:1) ZMF given to entitled zakah recipients (asnaf)especially from the hardcore poor (faqir) and the poor (miskin) categories to start a business. For this category, they do not have to repay the ZMF given to them. 2) ZMF given in term of soft-loan (qardhul hasan). This is a short term interest free loan given to the applicants who are in desperate need of loan. These applicants are expected to be able to recover and solve their business problem if ZMF assistance is given to them. For this category, they have to repay the ZMF advanced to them. As compared to the first category of ZMF, this program is very new to LZS and hence still under the trial period or probation period. ${ }^{14}$

The existence of financial assistance helps capital mustahiq business. This additional capital can be used as additional production costs so that the quantity of production can increase. The addition of production capacity with capital from zakat funds is intended to increase business income. The table below distributes the revolving venture capital assistance for small entrepreneurs in Makassar as follows:

\footnotetext{
${ }^{13}$ S. Zalikha, "Pendistribusian Zakat Produktif dalam Perspektif Islam," Jurnal Ilmiah Islam Futura 15, No. 2 (2016): 304-319. https://doi.org/10.22373/jiif.v15i2.547.

${ }^{14}$ P. Ibrahim, \& R.Ghazali, "Zakah as an Islamic Micro-Financing Mechanism to Productive Zakah Recipients," Asian Economic and Financial Review 4, No. 1 (2014): 117-125. 
Table 2. Number of Recipients of Zakat Funds Rolling in Makassar Since 2016-2018

\begin{tabular}{|c|l|c|c|}
\hline No. & Sub Districts & Number of Recipients $(\mathbf{F})$ & Percentage (\%) \\
\hline 1. & Tamalanrea & 19 & 30.16 \\
2. & Rappocini & 2 & 3.18 \\
3. & Mariso & 21 & 33.33 \\
4. & Tallo & 20 & 31.73 \\
5. & Biringkanaya & 1 & 1.59 \\
\hline & Amount & $\mathbf{6 3}$ & $\mathbf{1 0 0}$ \\
\hline
\end{tabular}

Data Source: Baznas Makassar, 2018

Based on the data above shows that as many as five (5) sub-districts out of fifteen (15) sub-districts received zakat funds in the Makassar. The district which received the most revolving funds for Mustahiq was Mariso Sub District, followed by Tallo Sub District and Tamalanrea Sub District. According to Abd. Aziz Bennu Baznas Makassar provided a revolving fund by directing the mustahiq to be creative and trying and this was done to alleviate poverty, direct the community to be able to stand alone by providing capital in the form of goods. So before the capital in the form of goods distributed previously had been held data collection related to the goods needed by the community mustahiq.$^{15}$ The following is the opinion of respondents regarding productive zakat in the form of revolving funds to mustahiq, as follows:

Table 3. Using of Revolving Fund

\begin{tabular}{|c|c|c|c|}
\hline No. & Statement & Frequency & Percentage (\%) \\
\hline 1. & For consumption & 11 & 36.67 \\
2. & For Business Activities & 19 & 63.33 \\
\hline & amount & $\mathbf{3 0}$ & $\mathbf{1 0 0}$ \\
\hline
\end{tabular}

Data Sources: Processed from Primary Data, 2018

Based on the data above illustrates that the results of interviews with the help of revolving venture capital for small entrepreneurs in Makassar are intended for business activities. However, there are also respondents (36.67) stating that the funds provided by Baznas Makassar are consumption (used up). Furthermore, respondents' opinions regarding the refund received from Baznas Makassar are as follows:

\footnotetext{
${ }^{15}$ Interview with Abd. Aziz Bennu Head of Distribution and Utilization of Makassar Baznas, July 16, 2018.
} 
Table 4. Zakat Refund

\begin{tabular}{|c|l|c|c|}
\hline No. & Statement & Frequency & Percentage (\%) \\
\hline \multirow{2}{*}{1} & Zakat funds returned & 4 & 13.33 \\
2 & $\begin{array}{l}\text { Zakat funds are not } \\
\text { returned }\end{array}$ & 26 & 86.67 \\
\hline & amount & $\mathbf{3 0}$ & $\mathbf{1 0 0}$ \\
\hline
\end{tabular}

Data Sources: Processed from Primary Data, 2018

The data above shows that most of the mustahiq who received revolving venture capital assistance for small businesses in Makassar (86, 67\%) did not want a refund. To support this data, the results of interviews with Saharia respondents (40 years) having their address at Jl. Kaluku Bodoa Rear Shipyard, as follows:

"I got a revolving fund from the Baznas Makassar, amounting to Rp.

1.000.000,00 (one million) rupiahs, but must be returned every month for Rp. 100.000,00 (one hundred thousand). In my opinion, zakat does not need to be returned". ${ }^{16}$

The same opinion of a receiver, Rina (32 years) having her address at Jl. Sultan Abdullah I of Tallo Urban Village, as follows:

"The zakat fund does not have to be returned because it is a property issued by a rich person, and I was a poor person has the right to receive zakat without the need to return". ${ }^{17}$

The data above illustrates that mustahiq recipients of revolving venture capital assistance for small entrepreneurs in Makassar want no return to the Baznas Makassar and consider that the zakat funds are used up (more consumptive rather than productive). The following table, respondents' opinions about the benefits of rolling capital, are as follows:

Table 5. Revolving Funds Benefit Mustahiq

\begin{tabular}{|c|l|c|c|}
\hline No. & \multicolumn{1}{|c|}{ Statement } & Frequency & $\begin{array}{c}\text { Percentage } \\
(\boldsymbol{\%})\end{array}$ \\
\hline 1 & Helpful & 29 & 96.67 \\
2 & Less useful & 1 & 3.33 \\
3 & Useless & - & - \\
\hline & \multicolumn{1}{|c|}{ Amount } & $\mathbf{3 0}$ & $\mathbf{1 0 0}$ \\
\hline
\end{tabular}

Data Sources: Processed from Primary Data, 2018

\footnotetext{
${ }^{16}$ Interview with Saharia, Recipients of Baznas Capital Aid, September 26, 2018.

${ }^{17}$ Interview with Rina, Recipients of Baznas Capital Aid, September 26, 2018. 
The data above shows that the majority of respondents stated that the provision of revolving venture capital assistance for small entrepreneurs in the Makassar. It was revealed by Nurlia (57 years) that the assistance provided by the Baznas Makassar provided benefits as capital, although it was temporary and the value was one million rupiahs". ${ }^{18}$ The same opinion was given by Anti (35) years which is located at Jalan Rear Shipyard that the money given by National Assistance Agency helped me in selling my business as capital, although it was not enough to increase my capital. ${ }^{19}$

Based on the results of the above interview with the recipients of the recipient of the revolving fund, it seems that the opinion of the respondents gave a positive appreciation of the revolving venture capital assistance for small entrepreneurs in Makassar. The results of the Baznas Makassar research, the provision of revolving venture capital assistance for small/micro-entrepreneurs varies from Rp. 1.000.000; 2.000.000; and 5.000 .000 and it is based on the results of data verification conducted by the Baznas Makassar.

Loans in the form of revolving funds is an effort to overcome poverty. It is based that the poor are divided into several classifications, namely: first, the very poor (the extreme poor) are those who are not income and have no productive activity; secondly, people categorized as poor but have economic activities (economically active working poor); and third, lower-income people who earn less but not much. In giving aid, priority is given to the poor who are in the near-poor group who are the poor who still have productive activities but are among those who have difficulty accessing capital and when there is economic turmoil, this group is the most vulnerable to be affected. The near-poor are prioritized in assisting to develop their business. ${ }^{20}$

\section{b. Mustahiq's Legal Perception Regarding Utilization of Productive Zakat in Makassar}

The Baznas Makassar channeled zakat, infaq and sadaqah funds for educational and social activities, these institutions channeled funds for productive business economic programs, including the development of agribusiness potential based on local excellence, empowerment of farmers and fishermen in the development of the real sector, and the economic development of poor people through the assistance of small businesses with guidance and assistance programs.

\footnotetext{
${ }^{18}$ Interview with Nurlia, Recipients of Baznas Capital Aid, August 28, 2018.

${ }^{19}$ Interview with Anti, Recipients of Baznas Capital Aid, August 28, 2018.

20 S. D. Wulansari, A. H. Setiawan, "Analisis Peranan Dana Zakat Produktif terhadap Perkembangan Usaha Mikro Mustahik (Penerima Zakat) (Studi Kasus Rumah Zakat Kota Semarang)," Diponegoro Law Journal of Economic 3, No. 1 (2013): 1-15.
} 
Table 6. Distribution of Revolving Funds in Baznas Makassar Since 2016-2018

\begin{tabular}{|c|l|c|c|}
\hline No. & $\begin{array}{c}\text { The Magnitude of } \\
\text { Funds (Rp) }\end{array}$ & $\begin{array}{c}\text { Number of } \\
\text { Recipients (F) }\end{array}$ & Percentage (\%) \\
\hline 1 & $1,000,000$ & 23 & 36.50 \\
2 & $3,000,000$ & 29 & 46.03 \\
3 & $5,000,000$. & 11 & 17.46 \\
\hline \multicolumn{2}{|c|}{ amount } & $\mathbf{6 3}$ & $\mathbf{1 0 0}$ \\
\hline
\end{tabular}

Data Source: Baznas Makassar, 2018

The empirical data above illustrates that from 2016-2018 a total of Rp. 165.000.000,00 funds are rolled out in the form of grants for revolving business capital for small/micro-entrepreneurs whose repayments are paid out for ten times without additional interest and other costs of capital received. For recipients of funds Rp. 5.000.000,00 returned capital assistance ten times in the amount of Rp. 500.000,00 every month. Recipient of Rp. 3,000,000, returning capital assistance ten times in the amount of Rp. 300.000,00 every month; for the recipient of funds Rp. 1.000.000,00 returning capital assistance ten times in the amount of Rp. 100.000,00 every month. This was done based on the Revolving Business Capital Loan Agreement signed by the Recipient as the Second Party and Baznas as the First Party. Furthermore, the respondents' opinions regarding the effectiveness of the revolving fund for working capital are as follows:

Table 7. Effectiveness of Utilization of Revolving Funds for Working Capital

\begin{tabular}{|c|l|c|c|}
\hline No. & \multicolumn{1}{|c|}{ Statement } & Frequency & $\begin{array}{c}\text { Percentage } \\
(\mathbf{\%})\end{array}$ \\
\hline 1 & Effective & 7 & 23.33 \\
2 & Less effective & 18 & 60.00 \\
3 & Ineffective & 5 & 16.00 \\
\hline \multicolumn{2}{|c|}{ amount } & $\mathbf{3 0}$ & $\mathbf{1 0 0}$ \\
\hline
\end{tabular}

Data Sources: Processed from Primary Data, 2018

The data above shows that most respondents stated that the revolving fund provided as working capital was less effective. The results of interviews with Sanni L (59 years), stay in Jalan Galangan Kapal Belakang that he received funding from Baznas Makassar, amounting to $\mathrm{Rp} .1 .000 .000,00$ of the funds I received were used more to meet my daily needs". ${ }^{21}$ The same statement was expressed by Ramlah (34 years), stay in

${ }^{21}$ Interview with Sanni, Recipients of Baznas Capital Aid, August 28, 2018. 
Jalan Galangan Kapal Belakang, that Baznas Makassar and not fully used for working capital but also bought food for daily needs. ${ }^{22}$

Based on the results of the above interview, the recipient of the revolving fund from the Baznas Makassar was not fully used for capital but was also used to buy daily basic needs. In its implementation, there is still misuse of assistance provided by the Baznas Makassar that uses the assistance to meet consumer needs. Furthermore, the data below shows the return of a revolving fund by mustahiq to Baznas Makassar as follows:

Table 8 . Revolving Refunds

\begin{tabular}{|c|l|c|c|}
\hline No. & \multicolumn{1}{|c|}{ Statement } & Frequency & Percentage (\%) \\
\hline 1 & Smoothly & 7 & 23.33 \\
2 & Not that smooth & 20 & 66.67 \\
3 & Not smooth & 3 & 10.00 \\
\hline & amount & $\mathbf{3 0}$ & $\mathbf{1 0 0}$ \\
\hline
\end{tabular}

Data Sources: Processed from Primary Data, 2018

The data above illustrates that mustahik who received revolving fund assistance from Baznas Makassar was not smooth in their return. It happened because the community made the funds used for consumptive purposes, in the case the funds should be used for a productive business. Further the results of the interview with Abd. Azis Bennu that:

"Based on the agreement made by the Baznas Makassar with a revolving fund mustahiq, the Second Party (community) promises to pay the capital assistance money every month for ten months no later than the tenth of the current month to be subsequently rolled out to the next recipient". 23

For refunds, set forth in Article 1 of the Rolling Business Loan Agreement, even Section 2 governs the breach that in the event the Parties default or fail to fulfil all of their obligations as outlined in this Agreement and or in the event of a violation by the Second Party to one or some of its obligations as set out in this Agreement, the First Party reserves the right to charge, at the same time, the amount of the loan, even if the terms of this agreement have not been met. Although there is already a written agreement regarding the refund, it appears that the refund is still ineffective.

The existence of revolving venture capital assistance from weak economic entrepreneurs can be an effective solution for mustahiq to get out of poverty support. Because with capital injections, and repayment of loans when they have benefited will motivate the mustahiq to try hard. The revolving fund assistance with one of its objectives is to prevent the

\footnotetext{
${ }^{22}$ Interview with Ramlah, Recipients of Baznas Capital Aid, August 28, 2018.

${ }^{23}$ Interview with Abd. Aziz Bennu Head of Distribution and Utilization of Makassar Baznas, July 16, 2018.
} 
mustahiq from the interest system in conventional banks, as well as loan sharks who appear during the lives of underprivileged people.

Utilization of zakat must have a positive impact on mustahiq, both in economic and social terms. From an economic standpoint, mustahiq is demanded to be able to live properly and independently, while seen from the social side, mustahiq is motivated to be able to live in line with other communities. It is shows that zakat is not only a practice that is distributed for consumptive matters but also the benefit of productive and creative mustahiq. ${ }^{24}$

Provision of revolving fund assistance conducted by the Baznas Makassar is one form of productive management that has a social entrepreneurship perspective. According to Mansur Efendi, this empowerment program is carried out by involving the community or community, both those who have social problems directly or not, to be educated and encouraged to help themselves by being involved in the process of solving these social problems. Changes in behaviour and transformation of empowered people's lives need to be the ultimate goal. Thus, the resolution of social problems can be carried out sustainably and independently by the community itself. ${ }^{25}$

\section{Conclusion}

Zakat is one of the pillars of Islam that must be fulfilled by all Muslims. Zakat in its implementation, must be determined and regulated by religion and the state. Makassar community perceives that productive zakat is the same position as consumptive zakat, which is spent on household needs. Mustahiq provided revolving funds through qardhul hasan loans more to pay for household needs or consumer goods so that it does not offer benefits as a productive business. Zakat funds in the form of qardhul hasan loans provided by the Baznas Makassar should be used for productive ventures. Besides, the people of Makassar community still perceive that the funds lent from the Baznas Makassar do not need to be returned because they consider that the funds are their rights as poor people and their use is for consumptive purposes and there is no obligation to return the zakat funds. Funding loans under the qardhul hasan scheme managed by Baznas Makassar are revolving and rotating in nature.

This research recommends is that the Baznas Makassar needs to intensify the socialization of the utilization of productive zakat on a massive scale so that people do not experience misperceptions about productive

\footnotetext{
${ }^{24}$ Utami, Lubis I, "Pengaruh Pendayagunaan Zakat Produktif Terhadap Pemberdayaan Mustahiq di Kota Medan," Ekonomi dan Keuangan 2, No. 6 (2014): 353-366.

25 M. Efendi, "Pengelolaan Zakat Produktif Berwawasan Kewirausahaan Sosial dalam Pengentasan Kemiskinan Di Indonesia," Al-Ahkam: Jurnal Ilmu Syariah dan Hukum 2, No. 1 (2017): 21-38. 
zakat. Baznas Makassar needs to intensify assistance to earning zakat earners so that the return of zakat funds is more effective.

\section{Acknowledgements}

This study was supported by a Research and Development Institute of Resources (LP2S) of UMI Makassar for funds of internal research. We greatly appreciate the contribution of Baznas Makassar gives data to authors.

\section{References}

Asnaini. Zakat Produktif Dalam Perspektif Hukum Islam. Yogyakarta: Pustaka Pelajar, 2008.

Efendi, M. "Pengelolaan Zakat Produktif Berwawasan Kewirausahaan Sosial dalam Pengentasan Kemiskinan Di Indonesia." Al-Ahkam: Jurnal Ilmu Syariah dan Hukum 2, No. 1, (2017): 21-38.

Hasan, M. T. Islam dalam Perspektif Sosio Kultural. Jakarta: Lantabora Press, 2005.

Amri, M. F. "Pemanfaatan Zakat Produktif Serta Pengaruhnya Terhadap Tingkat Pendapatan Mustahiq Di Kota Makassar (Studi Kasus Baitul Mal Kota Makassar)." Thesis Universitas Islam Negeri Sunan Kalijaga, (2017).

Sartika, Milla. "Pengaruh Pendayagunaan Zakat Produktif terhadap Pemberdayaan Mustahiq pada LAZ Yayasan Solo Peduli Surakarta." La_Riba 2, No. 1 (2008): https://doi.org/10.20885/lariba.vol2.iss1.art6.

Muhammad. Lembaga Ekonomi Mikro Syari'ah: Pergulatan Melawan Kemiskinan dan Penetrasi Ekonomi Global. Yogyakarta: Graha Ilmu, 2009.

Ibrahim, P, R. Ghazali. "Zakah as an Islamic Micro-Financing Mechanism to Productive Zakah Recipients", Asian Economic and Financial Review 4, No. 1 (2014): 117-125.

Qadir, A. Zakat dalam Dimensi Mahdhah dan Sosial. Jakarta: Raja Grafindo Persada, 2001.

Abdullah, Rose, A. R. A. Haqqi. "Zakah for Asnaf Al-Gharimun in Brunei Darussalam: Concepts and Practices." Al-Iqtishad: Jurnal Ilmu Ekonomi Syariah 9, No. 2 (2017): 243-258. https://doi.org/10.15408/aiq.v9i2.5092.

Wulansari, S. D, A. H. Setiawan. "Analisis Peranan Dana Zakat Produktif terhadap Perkembangan Usaha Mikro Mustahik (Penerima Zakat)(Studi Kasus Rumah Zakat Kota Semarang)." Diponegoro Law Journal of Economic 3, No. 1 (2013) : 1-15.

Zalikha, Siti. "Pendistribusian Zakat Produktif dalam Perspektif Islam." Jurnal Ilmiah Islam Futura 15, No. 2 (2016): 304-319. https://doi.org/10.22373/jiif.v15i2.547. 
Utami, Lubis I. "Pengaruh Pendayagunaan Zakat Produktif Terhadap Pemberdayaan Mustahiq di Kota Medan." Ekonomi dan Keuangan 2, No. 6 (2014): 353-366.

Khairuldin, W, W. M. K. Firdaus, M. Mohammad. "The Philosophy and Elasticity of Zakah Distribution in Islam." International Journal of Education and Research 1, No.8 (2013): 179-190.

Z, Zainuddin. "Hakikat Pengelolaan Zakat dalam Mewujudkan Jaminan Keadilan Sosial di Indonesia." Jurnal Penelitian Hukum Universitas Hasanuddin 1, No. 1 (2011): 110-129.

Z, Zainuddin. "Optimalisasi Peran Pemerintah Dalam Pengelolaan Zakat." Jurnal Ishlah 14, No. 1 (2012): 19-34.

Z, Zainuddin. "Pemaknaan Ulang Ar Riqab Dalam Upaya Optimalisasi Fungsi Zakat Bagi Kesejahteraan Umat." Jurnal Hukum Ius Quia Iustum 25, No. 3 (2018): 601-622. https://doi.org/10.20885/iustum.vol25.iss3.art9. 